\title{
Relation of Social Capital to Women's Proactive Participation in the Community for Sustainability of River in Urban Areas
}

\author{
Donna Asteria ${ }^{1}$, Alin Halimatussadiah ${ }^{2}$, Budidarmono $^{3}$, Dyah $_{\text {Utari }}{ }^{4}$, and Retty Dwi Handayani ${ }^{5}$ \\ ${ }^{1}$ Communication Department, Faculty of Social and Political Science, Universitas Indonesia, Depok, Indonesia \\ ${ }^{2}$ Faculty of Economics and Business, Universitas Indonesia, Depok, Indonesia \\ ${ }^{3}$ Faculty Law, Universitas Indonesia, Depok, Indonesia \\ ${ }^{4}$ Faculty of Health Science, Universitas Pembangunan Nasional Veteran, Jakarta \\ ${ }^{5}$ School of Environmental Science, Universitas Indonesia, Salemba, Indonesia
}

\begin{abstract}
The aims of this paper to identify a relationship of social capital with the participation of women in their community to realize the sustainablity of rive in urban areas and to achieve resilience of the city. Efforts to increase women's participation in urban planning and environmental management require the support of social capital in local contexts to achieve sustainability of river in urban areas. The method used in this research is a quantitative approach, with this type of research is descriptive-explanatory. Data collection techniques in this study by conducting surveys with questionnaire disseminating and literature study. The research location was undertaken in DKI Jakarta as the metropolitan city has the complexity of problems because of the density of citizens and environmental degradation, especially in the river area. The result of this study shows the social capital of the community has a relation to the proactive participation of women. The activity of capacity building for women for environmental management need to strengthen the values of togetherness and trust to actors who are the drivers of citizens and the implementers of community empowerment. The implication of this study can be used for strategy in protecting of the river in urban areas to adopting a more environmentally friendly approach by integrating gender equality.
\end{abstract}

Keywords: social capital; women participation; sustainability; river; urban areas

\section{Introduction}

Mitigation efforts to reduce greenhouse gas emissions from human activities as a prevention of increasing global warming can be done with environmental management. River conservation with riparian management and river cleaning will support low carbon communities [1]. This is important in low emission development planning in the cities with the participation of all citizens to achieve environmental sustainability. The emphasis on the integration of social aspects and environmental concerns in urban planning is essential to urban sustainability [2]. On the social issue, the citizens in the community as actors. For anticipating the climate change effect in the city, it is important to involve the citizens in the implementation of urban development. Climate change that causes severe impacts, not only on environmental damage but also on health, social and economic impacts. The resilience of cities should be

* Corresponding author: donna@ui.ac.id 
supported by people's ability to adapt to climate change situations. The ability of adaptation of citizens to face climate change will reduce the economic costs of the impact suffered as a consequence of losses on climate change, thus indirectly will provide economic resilience to the city. The strength of the adaptation of citizens to face climate change will reduce the economic costs of the impact suffered as a consequence of losses on climate change, thus indirectly will provide economic resilience to the city. So the condition of the local community requires the exploration of potential, one of which is by strengthening of social capital in the community [3]. Social sustainability is necessary to support the realization of environmental sustainability in urban areas. Especially in climate change situations as one of the caused by the increasing complexity of urban issues. The environmental management aspect becomes a mechanism to strengthen the resilience of the city to handle climate change effects. To achieve this requires the involvement of all citizens, especially women who are vulnerable due to environmental degradation of the city. Efforts to strengthen citizens in the community expect the support of social capital to increase the participation of women.

Capacity building by giving citizens chance to be involved in every aspect of urban development. Women need local community support because women are more vulnerable than men in the face of climate change impacts. Women's vulnerability is due to low knowledge of climate change and the limitation to participate in their communities. The case in Vietnam where women focus too much on their families so that they have little time to learn or update their knowledge of climate change and its impact [4]. However, women citizens can have a significant role in planning and decision making. One purpose of women who become environmental activists can do environmental communication to resolve environmental conflicts in Indonesia [5], women's leadership approach can increase community development in Malaysia [6] and the results of studies in Pakistan and the United States showing the contribution of women in building post-disaster resilience and promoting sustainable development [7]. In principle, the involvement of women in environmental the concept of SDGs corresponds to the point 5 and 11 that talks about the sustainability of the city [8].

The number of disasters in Indonesia in 2015 was recorded as many as 1,688 events, a decrease of 14 percent compared to 2014 which amounted to 1965 events. Putting picks, landslides and floods are the most common types of disasters. This disaster also occurred in DKI Jakarta, Indonesia, so that required anticipation and mitigation become part of urban planning. In particular, DKI Jakarta as the state capital requires better urban management planning by involving all levels of society. The impacts of climate-related disasters do not only cause material losses but also slow down economic activity. In 2013-2015 there were 48 floods with affected areas of more than 30 sub-district locations [9]. The consequences of such disasters lead to conditions of vulnerability and harm to society.
Efforts to strengthen citizens for adaptation face climate change and post-disaster situations need to be done by increase local forces. Resilience at the individual or household level relates to cultural resources, including literacy and education, and social resources, such as family and friends [10]. In sociocultural resources, capacity building for women citizens to participate in city environmental management will strengthen social networking for city sustainability. Network in social capital is one of the local forces that can facilitate citizen participation, so it needs to be explored as an approach for community empowerment in the community. Based on that, the purpose of this paper to describe the influence of social capital on the participation of women in their community to realize the resilience of the city.

\section{Theoretical review}

In this study environmental sustainability is a condition of balance, endurance, and the interconnectedness between human beings meet their needs, without exceeding capacity and its supporting ecosystem and without reducing biodiversity to keep regenerating [11]. Environmental sustainability in urban areas is the goal of urban planning requiring support from the realization of social sustainability. In relation to social sustainability, gender equality is needed in efforts to build community resilience,. A gender perspective is needed to understand the condition of women facing certain vulnerabilities due to the additional workload of livelihood activities and family care that women have to do [12]. In addition, women are also more vulnerable due to limited access to education and training, in addition to limited access and institutional information [13]. Thus, although participation is required from all walks of life, both women and men need to prioritize women's gender on decision-making, whether at the household level, community social activities, and local political and management structures [14]. It is also important to realize social justice in community development for urban planning, as in SDGs the-11 point..

To support the citizen involvement in urban development, social capital in the form of mutual support between neighbors, friends, community groups, and other social networks become a means to increase community resilience [15]. Social capital facilitates social relations and participation. Also social capital requires a local agent that can connect communities with resources and get support from the local government or NGOs [16]. The elements of social capital related to the existence of binding rules, with testing in this study consist of trust in between community (in the context of social networking), a value in society and solidarity in a community [17].

Based on the above description, in this study has a hypothesis to test about a relation of social capital to women's participation in the community, as follows: the variable $\mathrm{X} 1$ is trust in between community, the variable $\mathrm{X} 2$ is value in the community, and the variable $\mathrm{X} 3$ is 
solidarity in community as independent variables. And the variable Y (dependent variable) is women's proactive participation in the community. It shows in 'figure 1' below. The following hypotheses are formulated:

$\mathrm{H} 0$ : there is no positive relationship between the $\mathrm{X} 1, \mathrm{X} 2$ and $\mathrm{X} 3$ variables with the $\mathrm{Y}$ variable

$\mathrm{H} 1$ : trust in between community (X1) is a postive relationship with women's participation (Y)

$\mathrm{H} 2$ : value in community (X2) is a positive relationship with women's participation (Y)

H3: solidarity in community (X3) is a positive relationship with women's participation (Y)

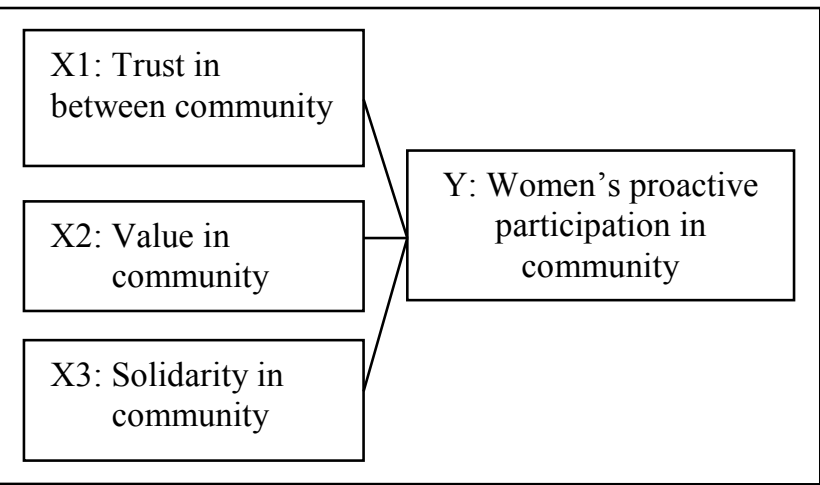

Figure 1. hypotetical model

\section{Methodology}

The method used in this reserach is quantitative approach, with this type of research is descriptiveexplanatory. Data collection techniques in this study by conducting surveys with quesioners disseminating and literature study. Sample selection technique with non probabilistic technique, with purposive sampling technique with criteria is female citizens who are active in local organizations for watershed environmental management in their communities. The research location was conducted in DKI Jakarta as a metropolitan city which became the capital of Indonesia. research data is done by distributing questionnaires to 100 respondents with technical descriptive statistical analysis. To maintain the quality of research data, also conducted reliability testing by using Cronbach's Alpha, in addition to testing the validity of using factor analysis and product moment analysis

\section{Results and discussions}

Based on the validity test, known KMO \& Barlet test results show the results of 0.749 , with a significance value of 0.000 , which indicates that the data is valid. Then the reliability test results with Cronbach's Alpha of 0.714 and Cronbach's Alpha based on standardized items of 0.716 for the four variables tested $(\mathrm{X} 1, \mathrm{X} 2, \mathrm{X} 3$, and $\mathrm{Y})$. These results show that reliable data and data are continued to be processed by Pearson correlation test and multivariate regression.

The hypothesis testing shows that $\mathrm{H} 1$ and $\mathrm{H} 2$ proved acceptable, while $\mathrm{H} 3$ was rejected. In the $\mathrm{H} 1$ shows a correlation between $\mathrm{X} 1$ (trust between in community) and Y (women's proactive participation in a community) with a significance value of 0.09 , with $\alpha=10 \%$. The hypothesis is accepted because the significance value is less than 0.1 . While in the $\mathrm{H} 2$, the assumption is proved that there is a relationship between $\mathrm{X} 2$ (value in a community) and $\mathrm{Y}$ (women's proactive participation in a community) with a significance value of 0.08 . The hypothesis is accepted because the significance value is less than 0.1 . The correlation value between the $\mathrm{X} 2$ variable and the $\mathrm{Y}$ variable is 0.471 that also the indication of the strength of the relationship is moderate. But the $\mathrm{H} 3$ hypothesis test is rejected because of the significance value of 0.13 . It's more than 0.1 (with the level of significance of $10 \%$ ). The hypothesis test results are not significant for solidarity variables between citizens with pro-active participation. The relationship test of the analysis with Pearson correlation showed the correlation value between the $\mathrm{X} 1$ variable and the $\mathrm{Y}$ variable is 0.440 , that the indication of the strength of the relationship is moderate. The correlation value between the X2 variable and the $\mathrm{Y}$ variable is 0.471 that also the indication of the strength of a relationship is moderate. In X3 variable shows the correlation value is 0.320 that the indication of the strength of relationship is moderate. It shows in "table 1".

Table 1. The result from Pearson correlation analysis

\begin{tabular}{|l|c|c|}
\hline Variable & $\mathrm{R}$ & P-value $(<0.1)$ \\
\hline $\mathrm{X} 1$ & 0.440 & 0.09 \\
$\mathrm{X} 2$ & 0.471 & 0.08 \\
$\mathrm{X} 3$ & 0.320 & 0.13 \\
\hline
\end{tabular}

The result of regression test shows that $\mathrm{R}$ is 0,419 and $\mathrm{R}$ square is 0,175 , base on the result, it means there are influence from the variable $\mathrm{X} 1$ and the variable $\mathrm{X} 2$ to the variable $\mathrm{Y}$.

Based on the results showed that the element of social capital that became the key in environmental management was the trust that formed the social network and the value of togetherness of the group members that became the norm of the community. Trust is strengthened through the presence of a critical person in a community with leadership to motivate citizens to participate in watershed management. Female citizens who play a crucial person are PKK executives who implement empowerment programs to improve the welfare of citizens. Concerning the role of local actors, the approach and leadership style of PKK officials is participating and delegating through the form of relational or convergence (two way) communication to women who have been members of the PKK or to people who have proactively participated in waste management and DAS in his community. However, to residents who have not attended, the PKK management still apply the 
leadership style of telling (assignment) with an efficient approach, in the form of direct communication to the citizens who are paternalistic (nonparticipative) to motivate the citizens.

The community's trust to implementers of empowerment activities for women in the community showed a result of $24 \%$ to private parties (activities as part of corporate CSR activities), 39\% to local NGOs, and $37 \%$ to local government. Empowering women is essential to building resilience and adapt to climate change. One form of support to increase women's by integrating policies that use gender perspectives by adjusting local conditions and intra-household level dynamics. The role of local organizations can foster women to engage in pro-active participation in environmental management. Access for women to join PKK (Pemberdayaan Kesejateraan Keluarga) as empowerment and family welfare organizations in their communities has provided an opportunity to gain knowledge on the impacts of climate change and how environmental management is being managed. PKK organizations in the community also interact with PKK organizations in different areas. It extends the women's social network to support each other and strengthen the resilience of environmental damage. The value of togetherness is realized through mutual assistance activities in the form of environmental management actions and exchanging information. Social capital in a society increasingly promotes social cohesion while increasing the participation and ability of women. Because river conservation through riparian management requires community support [18].

The development of a collaborative approach to environmental management requires innovative partnerships between central government, local government and women's organizations with the support of NGOs/stakeholders to establish social networking with key person/local leaders whose leadership can shape resilience. In relation to women's participation will be effective with the meso-level empowerment approach in the community (group) through a participatory approach. In addition, a social learning approach is needed for the formation of citizen participation in the community, especially for women to increase access to communication and interaction of women's participation in collective action [19].

Social capital become the basis for women's participation in their communities. However, the opportunity for women to contribute to environmental management can also improve social welfare and cohesion that strengthens the social ties of social capital in the community [20]. In addition, the partnership between the government and the community, including the stakeholders including the industry, has a role in the transfer of low carbon innovation knowledge through environmental management [21]. Women's participation should be supported by urban planning using a gender equality perspective to produce gender-sensitive policies [22]. Similarly, as an effort to improve the capacity of women, it is necessary to enact gender-sensitive education in the community to explore the potential of women leaders to take action on environmental management. The urban environmental sustainability requires the support of social sustainability in urban society through the participation of its citizens.

\section{Conclusion}

The result of this study shows the social capital of the community has a relation to the proactive participation of women. The strength of the social capital of trust and the value of togetherness in the community, not only strengthens the citizens but will increase the ability of individual women in improving their capacity. Thus, based on the development of women's organizations to build engagement between women's citizens at the local level in environmental management and adaptation of climate change impacts will strengthen resilience and environmental sustainability. With gender roles, women have an orientation towards their family welfare so that the importance of relationships and ties to the development of social networks. The purpose of government and local stakeholders is also needed to explore social capital as a strong bond in the community. This study as alternatives strategy for strengthening social capital in communities. It should be part of urban planning to increase community participation and to achieve urban environmental sustainability with the gender and environmental approaches in urban planning. This is crucial for sustainability, to attaining equity and realizing the balance in the management of natural resources and ecosystems with based of community in urban areas.

Social capital in the community related to gender aspects in this study provides an alternative perspective in pursuing the realization of environmental sustainability related to low carbon development. As an effort to conserve rivers, the restoration and revegetation of riparian areas contribute to carbon sequestration which is one form of mitigation of global warming. In addition, social capital shapes social adaptation capabilities by transferring knowledge to the community about the importance of supporting low-carbon community policies through the participation of all citizen

We gratefully acknowledge financial support from Ministry Research, Technology and Higher Education (Kemristekdikti) 2018 with Program Penelitian Dasar Unggulan Perguruan Tinggi (PDUPT) 2018, Directorate of Research and Community Service, Universitas Indonesia with contract number: 305/UN.2.R3.1/HKP05.00/2018

\section{References}

1. D.J. Lewis, M. Lennox, A. O'Geen, J. Creque, V. Eviner, S. Larson, J. Harper, M. Doran, K.W. Tate. University of California Cooperative Extension in Marin County: Novato, California (2015) 
2. L.Y. Shen, J. Ochoa, M.N. Shah, X. Zhang. Habitat International 351 17-29 (2011)

3. R. Putnam. Touchstone Books: New York USA (2001)

4. T.D.M Pham, T.T.S. Lam. Asian Cities Climate Resilience Working Paper Series 33 (2016)

5. D. Asteria, E. Suyanti, D.Utari, D.Wisnu. Procedia Environmental Sciences 20. 553 - 562 (2014)

6. Z. Hassan, A.D. Silong. European J. Scientific Research 233 361-372 (2008)

7. J. Drolet, L. Dominelli, M. Alston, R. Ersing, G. Mathbor, H. Wu. Gender \& Development 233 .433-448 (2015)

8. X. Zhang, C. Ma, S. Zhan, L. Lu. Applied Mechanics and Materials 174-177 2408-2011 (2011)

9. BPS-Statistics Indonesia. BPS-Statistics Indonesia (2016)

10. Heinz Center. The H. John Heinz III Center for Science Economics and the Environment (2002)

11. J. Morelli. J.Enviro Sustain 1. 1. 2 (2011)

12. G. Alber. Gender, www.mirror.unhabitat.org/downloads/docs/GRH S2011/GRHS2011ThematicStudyGender.pdf
(2011)

13. M. Alston. WIREs Climate Change 45 351-358 (2013)

14. P.T Tschakert, M. Machado. Ethics and Social Welfare 63 275-289 (2012)

15. R. Ersing. Surviving Disaster: The Role of Social Networks ed Ersing R and Kost K, Chicago: Lyceum Books (2012)

16. A. Krishna. Columbia University Press (2002)

17. I.R. Adi. FISIP UI Press (2007)

18. J. C. Stella, P. M. Rodri'guez-Gonza'lez, S. Dufour, J. Bendix Hydrobiologia 719 291315 (2013)

19. M. Muro, P. Jeffrey. J. Env Plan and Manage 53 325-344 (2008)

20. R Lestarini, E3S Web of Conferences 52, 00041 (2018)

21. S. Muchmore, G. Ragsdell, K. Walsh. 16th European Conference on Knowledge Management University of Udine: Italy, 3-4th. Sept 953-960 (2015)

22. TH Nafi, E3S Web of Conferences 52, 00048 (2018)

*Corresponding author: donna@ui.ac.id 